\title{
Genetic analysis of sleep
}

\author{
Amanda Crocker and Amita Sehgal ${ }^{\mathbf{1}}$ \\ Howard Hughes Medical institute, Department of Neuroscience, University of Pennsylvania School of Medicine, Philadelphia, \\ Pennsylvania 19104, USA
}

\begin{abstract}
Almost 20 years ago, the gene underlying fatal familial insomnia was discovered, and first suggested the concept that a single gene can regulate sleep. In the two decades since, there have been many advances in the field of behavioral genetics, but it is only in the past $\mathbf{1 0}$ years that the genetic analysis of sleep has emerged as an important discipline. Major findings include the discovery of a single gene underlying the sleep disorder narcolepsy, and identification of loci that make quantitative contributions to sleep characteristics. The sleep field has also expanded its focus from mammalian model organisms to Drosophila, zebrafish, and worms, which is allowing the application of novel genetic approaches. Researchers have undertaken large-scale screens to identify new genes that regulate sleep, and are also probing questions of sleep circuitry and sleep function on a molecular level. As genetic tools continue to be refined in each model organism, the genes that support a specific function in sleep will become more apparent. Thus, while our understanding of sleep still remains rudimentary, rapid progress is expected from these recently initiated studies.
\end{abstract}

Sleep is one of the great mysteries of science. It is a fundamental phenomenon with no known molecular function, despite the fact that it spans genetically diverse eukaryotes from higher-order phyla such as mammals to lower phyla such as arthropods (Tobler 2005). Within individual species, many characteristics of sleep are tightly regulated. These include, but are not limited to, the timing of sleep onset, depth of sleep, and average duration. Since all of these organisms show regulation of the same sleepassociated processes, the thinking is that conserved genetic mechanisms underlie sleep across species (Allada and Siegel 2008).

The recognition that sleep may be regulated by conserved genetic mechanisms has not yet led to a unified understanding of it. A closely related process - the generation of circadian rhythms-is now explained on the basis of a universal model, largely because of mechanistic studies done in phylogentically very diverse organisms. Studies of sleep have been primarily descriptive, consisting of lesion studies that have identified relevant anatomic areas in mammals, and pharmacological data that have pinpointed

[Keywords: Sleep; arousal; circadian rhythms; behavior in model organisms; model systems; genetics]

${ }^{1}$ Corresponding author.

E-MAIL amita@mail.med.upenn.edu; FAX (215)746-0232.

Article is online at http://www.genesdev.org/cgi/doi/10.1101/gad.1913110. effects of different neurochemicals. However, even these have not provided specific loci/foci to the extent known for circadian regulation, perhaps because these do not exist for sleep. For instance, there is still no specific anatomical area that can be lesioned to completely eliminate sleep. Likewise, if there is a specific neurotransmitter for sleep, it is still hypothetical. Thus, sleep does not appear to be controlled by a singe locus or dedicated genes. It is better understood as a broad system-wide phenomenon.

Hypotheses for sleep include somatic theories (healing of the body and other endocrine functions), cellular metabolic theories (removal of reactive oxidative species and energy replenishment), brain-specific functions such as synaptic plasticity (in adults, this would underlie memory consolidation), or synaptic downscaling. One needs to be careful with some of these hypotheses, since they are often based on detrimental effects of sleep deprivation, which is both a cellular and organismal stress due to the fact that it exceeds our normal physiological time awake. Given that wake-promoting pathways are involved in other biological functions, excess activity of these pathways could produce effects independently of sleep. Also, the sleep field is split between those who want to associate sleep function with specific aspects of brain electrical activity, as measured by an electroencephalogram (EEG) (described below), and those who want to understand what happens to the brain when it is offline, independently of the EEG.

Genetics provides a new way to address the regulation and function of sleep. While for the past 20 years genetics has been used primarily to verify lesion and pharmacological studies through targeted gene approaches, it can now be used to probe more intricate questions in sleep. Thus, forward genetic screens, inducible and anatomically specific genetic mutations, genetic alterations in synaptic signaling and excitability, genetic lesioning of cells, microarrays, and other genetic manipulations can be employed to identify novel mechanisms underlying sleep, and also to test specific hypotheses for sleep function.

This review focuses on the use of genetic and molecular techniques in model organisms to understand sleep. The first section provides the basic background of sleep research, and introduces the study of sleep from a genetic perspective. The second section focuses on the heritability of sleep traits and the genes underlying these traits. The third section describes the use of genetic manipulations in model organisms to understand the neurochemistry of sleep. The review ends with a discussion of recent studies designed to identify 
novel sleep-regulating genes, all of which have the ultimate goal of identifying sleep function.

\section{Background}

\section{The definition of sleep}

In the broadest sense, sleep is defined as a period of inactivity. This period is accompanied by an increase in arousal threshold, often in a stereotypical body position, and, if disrupted, is followed by a period of sleep rebound (Hendricks et al. 2000 Huber et al. 2004). This definition is applied to organisms as genetically simple as Caenorhabditis elegans, as well as to more complex organisms such as mice and even humans.

To understand sleep, two distinct aspects of it must be addressed. These are the timing of sleep and the length/ quality of sleep (Borbely 1982). Both are maintained to be approximately the same from day to day. The timing of sleep is well established as a function of the circadian system in the brain. The circadian system is important for driving many aspects of behavior and physiology with an $\sim 24$-h period through a set of molecular oscillators. How our body knows how much sleep we need is less understood. Based on the rebound, or compensatory sleep, that follows sleep deprivation, sleep is thought to be an essential process whose amount is controlled by a homeostatic system (Dauvilliers et al. 2005).

In mammals, sleep is identified empirically by physiological markers. In humans, as well as monkeys, rats, and mice, changes in brain activity during sleep and wakefulness can be monitored using an EEG, and different stages of these behavioral states have come to be identified by characteristic EEG patterns (wave forms) (Table 1; Allada and Siegel 2008; Ambrosius et al. 2008). These patterns are best defined in humans where a typical sleep EEG consists of one to three nonrapid eye movement (NREM) stages and a REM stage (Table 1). Stage $1 \mathrm{~N}$ is characterized by the transition from faster oscillations in the 8- to $13-\mathrm{Hz}$ range during wakefulness to oscillations in the 4- to 7-Hz range. Stage $2 \mathrm{~N}$ is characterized by sleep spindles (fast oscillations in the 12 - to $14-\mathrm{Hz}$ range) on top of the slower os- cillations. Stage $3 \mathrm{~N}$ is the deepest stage of sleep, and is composed of at least $20 \%$ slow, large-amplitude oscillations in the 0 - to $4-\mathrm{Hz}$ range known as delta waves; at its deepest points, this stage of sleep could consist of $>50 \%$ delta waves. (Dumermuth et al. 1983; Aeschbach and Borbely 1993). Depth of sleep is often characterized by the term "delta power," which refers to the frequency and amplitude of the delta waves produced. Delta power is hypothesized to be a readout of the homeostatic drive, so the higher the delta power, the greater the sleep pressure in the animal (Webb and Agnew 1971; Tobler and Borbely 1986). In other mammals, the sleep stages are less well defined, and generally fall into the categories of NREM, REM, or wakefulness (Tobler and Borbely 1986).

\section{Genetic approaches to the study of sleep}

The first clue that human sleep could be regulated genetically came from twin studies conducted in the 1930s (for review, see Dauvilliers et al. 2005). These studies showed that monozygotic twins are more likely to have similar sleep amounts and sleep onset times than dizygotic twins. After the invention of the EEG, it was found that monozygotic twins also show similarities in their EEG spectrum. Despite the fact that there is great variation in EEG spectrum from individual to individual, within monozygotic twins, it is highly correlated (Anokhin et al. 1992; Steinlein et al. 1992; van Beijsterveldt and Boomsma 1994; Ambrosius et al. 2008). As discussed below, more recent studies have validated the genetic basis of the EEG pattern, and even identified genetic loci that underlie these traits.

Mice have $\sim 85 \%$ genetic similarity to humans, and so provide an excellent model for the genetic analysis of sleep (Church et al. 2009). They also display characteristic EEG traces, and periods of sleep that are regulated by the same homeostatic and circadian mechanisms as in humans (Allada and Siegel 2008). However, there are several drawbacks to using a mouse model: They have a long generation time. They are likely to show compensation or redundancy in genes critical for the survival of the mouse, many of which may be important for sleep. Also, until recently, genetic tools were not available to alter the

Table 1. Terms commonly used to describe sleep

\begin{tabular}{ll}
\hline Electroencephalogram (EEG) & $\begin{array}{c}\text { Glossary } \\
\text { Wake EEG } \\
\text { of activity in the underlying cortical neuronal populations. } \\
\text { Small-amplitude, high-frequency oscillations. These waves are produced as a result of } \\
\text { desynchrony in firing between cortical neurons. } \\
\text { Larger-amplitude, lower-frequency oscillations that are thought to reflect the transition } \\
\text { of these neurons to a more synchronous and bursting firing pattern. } \\
\text { Small-amplitude, high-frequency oscillations that look like the waking EEG, but are } \\
\text { accompanied by loss of muscle tone and the presence of REM. } \\
\text { Stage N3 and the deepest stage of sleep. This is when the synchrony in neuronal firing is } \\
\text { thought to be at its highest. There is also the presence of delta waves, which are the } \\
\text { slowest- and largest-amplitude EEG waves seen during sleep. }\end{array}$ \\
Slow wave sleep & $\begin{array}{l}\text { The density of delta waves; this is thought to reflect one's need for sleep. } \\
\text { The timing of sleep. }\end{array}$ \\
The depth or length of sleep. & \\
Circadian component of sleep & Themeostatic component of sleep
\end{tabular}


expression of genes over time or spatially within the mouse brain (Rossant and McMahon 1999).

Simpler organisms such as C. elegans, Drosophila melanogaster (fruit fly), and Danio rerio (zebrafish) are all also proving to be excellent models for sleep (Allada and Siegel 2008; Cirelli 2009). They share the advantage that they are all genetically tractable, and have relatively simple genomes (the worm and the fly also have very short generation times). In addition, they all have the ability to generate both simple and complex behaviors (Sokolowski 2001). Lower redundancy of the genome in these organisms makes it easier to identify genes important for sleep. Research in these model organisms has also seen a burgeoning of genetic tools that can be used to probe sleep, ranging from technology that allows for precise temporal and spatial control of genes to reagents that can bypass the need for electrophysiology.

While the utility of the model organisms listed above is unquestionable, it is important to note that the genetics of sleep is not restricted to these organisms. Family-based linkage studies and genome-wide association studies are pinpointing sleep genes in humans (Winkelmann et al. 2007; Hallmayer et al. 2009). In addition, advances in the genetics of sleep have sometimes come from unexpected systems. For instance, a dog model for narcolepsy led to the identification of a gene underlying this disorder, and a circadian rhythm mutation, tau, was found fortuitously in a hamster (Ralph and Menaker 1988; Lin et al. 1999).

\section{Genetic analysis of sleep traits}

\section{Natural variations in sleep traits}

While earlier work focused primarily on wake EEGs, more recent studies have examined EEGs during sleep (Ambrosius et al. 2008; De Gennaro et al. 2008). De Gennaro et al. (2008) showed recently that frequencies of $8-16 \mathrm{~Hz}$ during NREM sleep show a high amount of heritability, regardless of sleep need or intensity. Despite these studies, very little familial linkage work has been done on EEG sleep traits.

Large-scale mapping studies of genetic differences in sleep architecture between inbred mouse strains (QTL mapping) has allowed researchers to isolate genes that underlie subtle differences across strains (O'Hara et al. 2007). One study focused on theta oscillations, which vary in frequency across inbred strains, but very little within a strain. Tafti et al. (2003) looked specifically at the difference between the Balb/cByJ mice, which have "slow" theta frequencies on the EEG, and c57Bl/6J mice, which have "fast" theta rhythms. In mice, hippocampal-derived theta rhythms in the 6- to $10-\mathrm{Hz}$ range are seen during REM sleep and exploratory activity, including wheel running. This is different from the cortical theta rhythms seen in humans in stage $\mathrm{N} 1$ of sleep that are in the 4- to 7-Hz range. Tafti et al. (2003) were able to narrow down the region of interest to a single gene on chromosome 5 known as Acads (short-chain acyl-coenzyme A dehydrogenase). They found that Balb/cByJ mice have a deficiency in Acads, which underlies the slowing of the theta rhythm.

Another successful QTL study identified a gene on chromosome 14, Rarb, that contributes to the 1- to $4-\mathrm{Hz}$ delta frequency in mice (Maret et al. 2005). Taking a reverse genetic approach to specifically target the Rarb gene, Maret et al. (2005) showed that retinoic acid signaling (the pathway Rarb functions in) is important for modulating cortical synchrony during NREM sleep.

Later in this review, we touch on some of the ion channels that have been mutated to alter the EEG pattern. Since the channels probably account more directly for the oscillatory bursting of the sleep EEG, they may be regulated by some of the genes discussed above. However, while these studies are important for the insights they provide regarding the genetic control of the sleep EEG, they do not reveal the significance of these waves. Nor, for that matter, do they allow association of EEG patterns with sleep function.

\section{Circadian influences on sleep}

As mentioned above, the circadian regulation of sleep is much better defined than the homeostatic regulation. In addition, the molecular basis of circadian control is quite well understood, as a result of cross-disciplinary approaches that include organisms as simple as cyanobacteria and Neurospora (Sehgal 2004). Molecular mechanisms of the circadian clock are indeed conserved from cyanobacteria to humans. From Drosophila to humans, the molecules are also largely conserved, and have even been implicated in human circadian disorders. The mammalian molecular clock mechanism described below does not do justice to the current state of knowledge in this field; its brevity can be attributed to the fact that it has been covered in countless other reviews, and the need to focus this writing on the homeostatic regulation of sleep.

The circadian system in mammals and invertebrates involves molecular feedback loops within cells that can maintain an 24-h rhythm (Siepka et al. 2007). In all of these organisms, the core components of the clock are broken into positive and negative regulators. In mammals, $B M A L 1$ and NPAS2/CLOCK are the positive regulators that drive the transcription of Per (Period) and Cry (Cryptochrome), which feed back and inhibit the transcription of BMAL1 and CLOCK/NPAS2, thereby forming the negative regulators. Following degradation of the negative regulators, a new cycle begins. Mice mutant for any of these genes, or combinations of these genes, generally display aberrant rest:activity patterns, although redundancy often results in weaker phenotypes than predicted.

As one would expect, the circadian system is important in determining the timing of sleep. This is best demonstrated in a disorder known as familial advanced sleepphase syndrome (FASPS), which results in very early sleep and wake times. Genetic studies have identified a mutation in the Casein kinase $1 \delta$ gene in one family afflicted with FASPS, and a mutation in the period gene, which affects the interaction of the period protein with Casein kinase 1, in yet another family (Toh et al. 2001; Xu et al. 2005). Remarkably, both of these genes were first identified in Drosophila as part of the circadian clock, thereby attesting to the conservation of molecular mechanisms (Konopka and Benzer 1971; Kloss et al. 1998). Interestingly, 
the Tau mutation in the hamster that causes a very short period is an allele of Casein Kinase $1 \varepsilon$ (Lowrey et al. 2000).

The FASPS mutations do not change overall sleep time, but do alter (advance) the timing of sleep onset. The same phenotype is produced when either Per 2 or Casein kinase $1 \delta$ is mutated in the mouse, but in flies, the equivalent mutation in Casein kinase $1 \delta$ results in a phase delay (Xu et al. 2005). Thus, this particular amino acid is also important in flies, although the regulation may be somewhat different.

Naturally occurring polymorphisms in circadian clock genes do not cause extreme phenotypes like FASPS, but can have effects on the timing of sleep. Indeed, several studies have attempted to correlate such polymorphisms with preferences for early wake-up times (seen in "morning" types or "larks") or late sleep times ("evening" types or "owls") (Archer et al. 2003; Carpen et al. 2005, 2006; Viola et al. 2007). The C allele of the T2434C polymorphism in Perl is associated with morningness and disruptions in sleep timing (Carpen et al. 2006).

It is clear that circadian genes affect the timing of sleep. What still remains debatable is whether they have a role in the homeostatic regulation of sleep; i.e., in determining sleep amount. There is some evidence to this effect. Mice with mutations in some core circadian genes such as $C L O C K, B M A L$, and Cry, as well as other circadian regulators, show changes in sleep amount. Clock mutant mice sleep on average $2 \mathrm{~h}$ less than their wild-type littermates (Naylor et al. 2000). The BMAL knockout mice and the CRY1/CRY2 double-knockout mice both show increases in their total sleep time (Wisor et al. 2002b; Laposky et al. 2005). A knockout of Prokineticin 2, which is a possible output signal from the SCN (suprachiasmatic nucleus, center for circadian rhythms in mammals), shows reduced total sleep and attenuated sleep rebound following a period of deprivation (Hu et al. 2007). Likewise, mutations in some circadian genes in fruit flies also have disruptions in the sleep homeostat (Shaw et al. 2002; Hendricks et al. 2003; Chung et al. 2009; Donlea et al. 2009)

A recent study implicated yet another circadian gene in the regulation of sleep length. Dec2, a basic helix-loophelix (bHLH) protein, is thought to function in the clock as a repressor of Clock/Bmal1 (Honma et al. 2002). The recent study found a point mutation in the Dec2 gene in a family of short sleepers (He et al. 2009). These people fall asleep at a normal time, unlike people with advancedphase syndrome, discussed above, but wake up early so that their average amount of sleep is $\sim 6 \mathrm{~h}$ (He et al. 2009). In mice, knockout of Dec2 did not result in a decrease in sleep, as does the point mutation in humans. But, when the specific point mutation was introduced into the mouse, it decreased sleep time, without affecting circadian period, suggesting that it has a dominant effect. Interestingly, a role for Dec2 is conserved in flies (Lim et al. 2007).

Flies generated to express the mouse Dec2 gene carrying the P385R mutation showed a sleep phenotype similar to that seen in mammals (He et al. 2009).

Even with these effects of circadian genes on sleep amount, it remains unclear as to whether the circadian clock affects sleep homeostasis. For one, the effects are small. For another, they have not been reported for all clock genes. Finally, for the genes that have been implicated, the sleep phenotypes could reflect pleiotropic or noncircadian effects of these genes.

\section{The genetics of sleep neurochemistry}

The first book on the anatomy of sleep was published in the 1840s (Edelson 1992). Since that time, most of our understanding of sleep neurochemistry has relied on physiological and pharmacological studies. But, over the past $10-20$ years, genetics has emerged as a major tool to investigate sleep neurochemistry as well as the circuitry associated with it. Indeed, much of the earlier physiolog$\mathrm{ical} /$ pharmacological work in mammals is now supported by genetic approaches, and has been summarized in many excellent reviews and anatomical maps (Saper et al. 2005; Andretic et al. 2008a). More recently, there has been a surge of genetic studies identifying sleep-regulating areas and neurochemicals in the fly brain (see Fig. 1).

The neurochemical analysis of sleep has involved characterization and manipulation of the major neurotransmitter systems, as well as their receptors. Genetic approaches have classically created and/or characterized targeted knockouts of candidate molecules, and identified new roles or confirmed old roles for many of these in sleep. We provide below a brief outline of how genetic modifications in the biosynthetic or signaling pathways of different

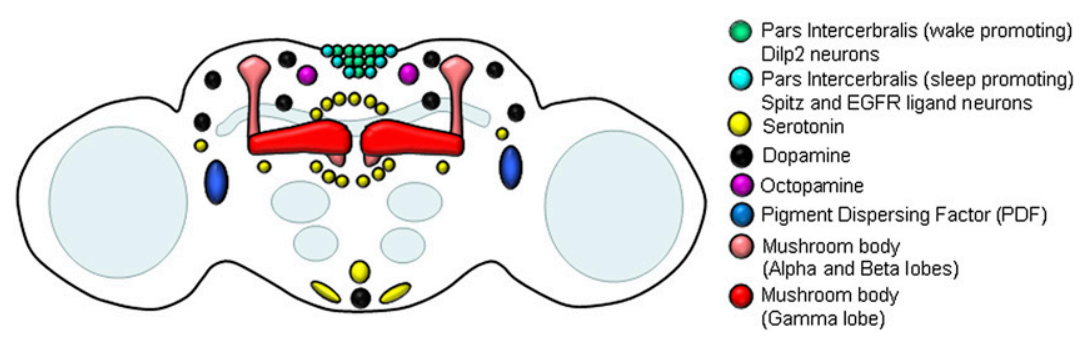

(black and yellow). PDF-producing large ventral lateral neurons (LNv) are important for promoting arousal in response to light and are shown in blue. Despite not knowing where the neurotransmitter signals originate, areas that receive these signals have been identified (PI neurons or mushroom body). Manipulation of intracellular signaling pathways has also implicated these areas (PI neurons and mushroom body).

Figure 1. Brain regions in the fly important for sleep-wake regulation. Many of the major neurotransmitter systems within the fly have been analyzed for their role in sleep. In the biogenic amine category, only octopamine has been localized to a specific cell group relevant for its role in sleep-wake behavior (purple). Dopamine and serotonin play a role in the regulation of sleep, but the specific subgroups of cells have not been mapped, and thus the major cell groups that produce these transmitters are shown in this figure that receive these signals have been identified (PI
mplicated these areas (PI neurons and mushroom 
neurotransmitters have provided insights into sleep neurochemistry. A list of these neurotransmitters-as well as other genes-that affect sleep across species is provided in Table 2.

\section{Hypocretin/orexin}

The discovery of the orexin, also known as hypocretin, gene represents one of the most significant advances in sleep research in the past 20 years. Its role in narcolepsy was discovered independently by two laboratories: one studying canine narcolepsy, and the other studying feeding behavior. The focus of Dr. Mignot's group at Stanford University (Lin et al. 1999) was on cloning the narcolepsy gene. Using a breed of dogs afflicted with narcolepsy, they were able to map the relevant mutation to the gene encoding the hypocretin receptor (hcrtrt2). Dr. Yanagisawa's group at University of Texas Southwestern /Chemelli et al. 1999|, on the other hand, had identified ligands of orphan G-protein-coupled receptors, and ,in studying the phenotype of a knockout mouse lacking one of these ligands, orexin, found that it showed narcoleptic behavior It became clear from these and subsequent studies that orexin plays a critical role in stabilizing sleep and wake cycles by influencing both wake-promoting and sleeppromoting areas of the brain (Mochizuki et al. 2004; Saper et al. 2005). Its major role is as a wake-promoting signal; in its absence, animals have trouble maintaining wakefulness and lapse rapidly into REM sleep. People with narcolepsy typically lack orexin-producing neurons for reasons that may have to do with altered immune function (Hallmayer et al. 2009).

Orexin has also been studied in zebrafish, but its role there is slightly more controversial, with conflicting studies reporting insomnia-like phenotypes of both the overexpression and knockout models (Prober et al. 2006; Yokogawa et al. 2007). There is also controversy over the projection pattern of orexin neurons and the localization of the fish orexin receptor (Kaslin et al. 2004; Yokogawa et al. 2007). Further studies in zebrafish will be needed to tease apart the role of orexin.

Flies do not have orexin, but it is hypothesized that pigment-dispersing factor (PDF), which is released from central clock neurons, is the fly equivalent of orexin. Some of these neurons (the large cells) play an important role in promoting wakefulness in the fly in the early morning, and this is done through PDF (Fig. 1; Parisky et al. 2008; Shang et al. 2008; Sheeba et al. 2008a; Donlea et al. 2009). It is hypothesized that PDF acts much as orexin does in mammals-as a stabilizer of sleep and wake. Flies that lack PDF signaling, either by disruption of the PDF gene, ablation of PDF neurons, or lack of the PDF receptor, show defects in their ability to respond to the "lights on" transition, and thus have reduced activity levels at the beginning of their day (Shang et al. 2008; Chung et al. 2009). They also show increases in overall sleep amounts with increased transitions from wake to sleep. Some of this action appears to be mediated through GABAergic inputs onto PDF neurons (Parisky et al. 2008; Chung et al. 2009). Additionally, flies with hyperexcitable PDF neu- rons show lower levels of sleep (Shang et al. 2008; Sheeba et al. 2008a,b). Thus, the effect of PDF on sleep levels and consolidation is similar to that of orexin in mammals.

\section{Acetylcholine}

Genetic analysis of acetycholine has been difficult in most organisms due to the many biologically essential functions of this neurotransmitter. In addition, there is a very large number of nicotinic and muscarinic acetylcholine receptors and receptor subtypes. Thus, the role of acetylcholine in sleep has, to date, been better studied using pharmacological approaches, which indicate that acetylcholine is part of the arousal system, critical for the waking EEG and REM sleep (Saper et al. 2005). For the few nicotinic receptor mutants analyzed for sleep, only minor changes in sleep architecture have been reported (Lena et al. 2004; Fonck et al. 2005). On the other hand, a mutation in the muscarinic acetylcholine receptor $\mathrm{M} 3$ results in a decrease in REM sleep (Goutagny et al. 2005). Targeted genetic disruption of the acetylcholine receptor subtypes within small populations of neurons, such as with RNAi technology or genetically designed viruses, may be more informative. It is also possible that acetylcholine does not actually regulate sleep, but that sleep stages regulate acetylcholine, as suggested by Gais and Born (2004).

\section{The biogenic amines}

The role of norepinephrine, dopamine, serotonin, and histamine in sleep has been covered exhaustively (Saper et al. 2005; Dzirasa et al. 2006; Monti and Monti 2007; Berridge 2008; Monti et al. 2008; Cirelli 2009). For this reason, we limited our discussion of these neurotransmitters. In brief, targeted genetic disruptions of the biogenic amines-specifically, norepinephrine, dopamine, and histamine-have confirmed the wake-promoting actions of these neurotransmitters suggested by lesion and pharmacological approaches (Wisor et al. 2001; Vallone et al. 2002; Hunsley and Palmiter 2003; Ouyang et al. 2004; Popa et al. 2005; Waddington et al. 2005; Hunsley et al. 2006; Monti and Monti 2007; Qu et al. 2008). Serotonin, on the other hand, has had a more complicated history, since it may have different effects on REM versus NREM sleep. It is clear from genetic and pharmacological studies that it inhibits REM sleep (Boutrel et al. 1999, 2002), but it may actually promote NREM sleep (Jouvet 1968).

One area in which genetic targeting studies have provided novel insight is in the role of histamine in narcolepsy. Mice carrying a mutation in histamine decarboxylase $(H D C)$ show altered levels of sleep-hypersomnolenceand are unable to maintain wakefulness during times of normally high vigilance, such as light transitions and cage changes (Parmentier et al. 2002). This phenotype is similar to that of narcolepsy, and, in fact, a role of histamine in this disease is being investigated. Both orexin knockout mice and $H D C$ knockout mice show sleep fragmentation and increased REM, but the HDC knockout mice show increased REM during the light phase when mice normally 
Table 2. Genes implicated in homeostatic regulation of sleep through genetic studies across species

\begin{tabular}{|c|c|c|c|c|}
\hline & Mammals & $\begin{array}{c}\text { Fruit fly } \\
\text { (D. melanogaster) }\end{array}$ & $\begin{array}{l}\text { Zebrafish } \\
\text { (D. rerio) }\end{array}$ & $\begin{array}{c}\text { Worms } \\
\text { (C. elegans) }\end{array}$ \\
\hline \multirow[t]{7}{*}{ Circadian genes } & Period 1,2,3 & Period & & $\begin{array}{l}\text { Lin-42 (per } \\
\text { homolog) }\end{array}$ \\
\hline & Bmal1 & Cycle & & \\
\hline & NPAS2/Clock & Pigment-dispersing & & \\
\hline & Prokineticin 2 & factor $(P D F)$ & & \\
\hline & Cry1/Cry2 & & & \\
\hline & CK1 $\delta$ & & & \\
\hline & Dec2 & & & \\
\hline \multicolumn{5}{|l|}{ Neurotransmitters } \\
\hline \multirow[t]{6}{*}{ Serotonin } & Sert & $T R H$ & & \\
\hline & 5-HT1a & 5-HT1a & & \\
\hline & 5-HT1b & & & \\
\hline & 5-HT2a & & & \\
\hline & 5-HT2c & & & \\
\hline & 5-HT7 & & & \\
\hline \multirow[t]{2}{*}{ Dopamine } & $D A T$ & Fumin & & \\
\hline & & DopR1 & & \\
\hline \multirow{2}{*}{$\begin{array}{c}\text { Norepinephrine } \\
\text { (octopamine) }\end{array}$} & $\mathrm{DbH}$ & $T b H$ & & \\
\hline & & $T d c$ & & \\
\hline Histamine & $H D C$ & & & \\
\hline \multirow[t]{3}{*}{ Acetylcholine } & $\begin{array}{l}\text { Chrm3 (muscarinic } \\
\text { AchR M3) }\end{array}$ & & & \\
\hline & Chrm2/4 (muscarinic & & & \\
\hline & $A \operatorname{chR} M 2 / 4)$ & & & \\
\hline Orexin/hypocretin & Orexin/Hcrtrt2 & $\boldsymbol{P D F}$ (hypothesized to & Hcrt overexpression & \\
\hline & & function similarly) & Hcrtrt2 & \\
\hline \multirow[t]{2}{*}{ Adenosine } & A2 a receptor & & & \\
\hline & A1 receptor & & & \\
\hline GABA & & $R d l$ (GABA receptor) & & \\
\hline \multirow{4}{*}{$\begin{array}{l}\text { Cytokines/immune } \\
\text { or stress response genes }\end{array}$} & NFкB1 & & & \\
\hline & Bip & Relish $($ NFאB $)$ & & \\
\hline & $T N F-\alpha$ & Bip & & \\
\hline & $I L-1 b, I L-6, I L-10$ & & & \\
\hline \multirow{4}{*}{$\begin{array}{l}\text { Synaptic } \\
\text { transmission genes }\end{array}$} & Homer1a & Homer & & \\
\hline & $d n S N A R E$ & & & \\
\hline & $c$-Fos & & & \\
\hline & Gria3 & & & \\
\hline \multicolumn{5}{|l|}{ Ion channels } \\
\hline \multirow[t]{4}{*}{$\mathrm{K}^{+}$channels } & Kv1.2 & Shaker & & \\
\hline & Kv3.1 & Hyperkinetic & & \\
\hline & Kv3.3 & Sleepless & & \\
\hline & Kv3.2 & & & \\
\hline \multirow[t]{2}{*}{$\mathrm{Ca}^{++}$channels } & Cav2.2 & & & \\
\hline & Cav3.1 & & & \\
\hline \multicolumn{5}{|l|}{ Signal } \\
\hline \multirow{5}{*}{$\begin{array}{l}\text { Metabolic/cellular } \\
\text { growth genes }\end{array}$} & Ghrelin & Rho (enzyme in & & EGFR (Let-23) \\
\hline & Leptin & EGFR Pathway) & & EGF (Lin-3) \\
\hline & Dwarf (GHRH) & Spitz $(T G F-a)$ & & \\
\hline & GHRHR & Star & & \\
\hline & $\begin{array}{l}\text { MT-rGH (growth } \\
\text { hormone) }\end{array}$ & & & \\
\hline \multirow{5}{*}{$\begin{array}{l}\text { Learning and } \\
\text { memory genes }\end{array}$} & Prkg1 (PKG) & Foraging (PKG) & & Egl-4 (PKG) \\
\hline & CREB & dCREB $2 b$ & & \\
\hline & $\alpha / \delta$ & Dunce $(P D E)$ & & \\
\hline & & $P K A$ & & \\
\hline & & Rutabaga $(c A M P)$ & & \\
\hline \multirow[t]{2}{*}{ Genetic disorders } & Ube $3 A$ & dUbe3a & & \\
\hline & FMR1 & dFMR1 & & \\
\hline
\end{tabular}

All of the genes listed here have been analyzed for effects on sleep through genetic analysis, knockout, knock-in, or other mutants. Genes in bold are implicated in sleep in multiple species. 
sleep (Anaclet et al. 2009), whereas orexin mutants display REM during waking hours. In support of the role histamine may play in narcolepsy, patients with narcolepsy have decreased levels of histamine in their cerebral spinal fluid (Nishino et al. 2009). These data begin to underscore the more complicated aspects of sleep-wake regulation.

Many environmental cues and inputs can promote wakefulness, and, similarly, there appear to be many neurotransmitter systems important for the response to each of those cues. Mice have periods of wakefulness following introduction to a novel environment such as new cages or new lighting, as well as increased arousal during and following locomotor tasks. Histamine may play a critical role in the EEG spectrum of sleep during the day when mice sleep, as well as in arousal induced by novel environments (Anaclet et al. 2009). Orexin, on the other hand, is connected to the wakefulness seen during the night (the mouse's active period), and is necessary to maintain arousal during and after locomotor tasks (Anaclet et al. 2009).

Unfortunately, both pharmacological studies and genetic studies conducted to date suffer from potential drawbacks. For one, pharmacological studies rely on injections that may not be very specifically targeted. In addition, an agonist or antagonist can often have extraneous effects. On the other hand, genetic deletions, particularly those that occur during development, are frequently compensated by the animal. Also, since molecules can have different functions in different regions, analysis of global knockouts typically does not yield clear-cut results. Perhaps for this reason, sleep phenotypes of genetic knockouts are often complicated, and sometimes controversial (Boutrel et al. 1999, 2002; Frank et al. 2002; Wisor et al. 2003; Hedlund et al. 2005; Waddington et al. 2005; Alexandre et al. 2006; Monti and Monti 2007). In order to address the role of each receptor in sleep, inducible and anatomically specific knockouts need to be generated. Moreover, to control for redundancy, it may be necessary to generate animals lacking multiple receptors.

Interestingly, virtually all of these neurotransmitterse.g., dopamine, serotonin, and octopamine (the invertebrate counterpart of norepinephrine)-regulate sleep in other model organisms such as the fly (Fig. 1; Kume et al. 2005; Chang et al. 2006; Yuan et al. 2006; Andretic et al. 2008b; Crocker and Sehgal 2008; MN Wu et al. 2008; Lebestky et al. 2009; Crocker et al. 2010). While the work on dopamine and octopamine has confirmed that they constitute wake-promoting signals as they do in mammals, serotonin in the fly provides a sleep-promoting signal (Yuan et al. 2006). In general, analysis in the fly is simpler because, thus far, only one sleep state is known, there are fewer receptors for each neurotransmitter, and there is also less compensation and redundancy. It is also possible to map sleep-regulating effects of a molecule to specific subsets of neurons through an unbiased genetic approach. Not only does this provide anatomical information, it also allows visualization of phenotypes produced by manipulation of just those cells. Using this approach, we showed recently that only a subset of octopamine-producing cells is responsible for its wake-promoting signal (Crocker et al. 2010).
Although wake-promoting neurotransmitters are clearly important in determining sleep amount, there is much more interest in sleep-promoting molecules, since these could more directly be part of the sleep homeostat. At the very least, they are required for implementation of sleep drive. Known sleep-promoing neuromodulators are discussed below.

\section{GABA}

GABA is a major sleep-promoting neurotransmitter that, when released from the ventral preoptic area (VLPO) in mammals, inhibits wake-promoting areas (Gong et al. 2004). In addition, release of GABA from the nucleus reticularis of the thalamus, and its action on other thalamic nuclei, promotes the transition from a wake to a sleep EEG (Cope et al. 2005). While pharmacological studies have implicated the GABA-A receptor in sleep generation, genetic mutants of the pathway show minimal phenotypes. Mice carrying a point mutation in the GABA-A receptors a1-a3 show no changes in sleep (Tobler et al. 2001; Kopp et al. 2003, 2004). The GABA-A receptor a3 subunit knockout mice display normal sleep amounts, but have reduced spindle activity $(10-$ to $15-\mathrm{Hz}$ range during NREM-REM transitions) (Winsky-Sommerer et al. 2008). The knockout of the GABA-A receptor $\mathrm{d}$ subunit has only been examined after drug treatment, and it shows normal EEG patterns (Winsky-Sommerer et al. 2007). The role of the GABA-A receptor b3 subunit has been controversial, with conflicting results on whether there is an effect on sleep and delta power (Laposky et al. 2001; Wisor et al. 2002a). Redundancy in the GABA signaling pathway likely accounts for these questionable phenotypes.

In summary, genetic analysis of neurotransmitters that are widely distributed and necessary for life, such as GABA and glutamate, has proven to be very difficult in mammals. However, the Drosophila, C. elegans, and, recently, zebrafish models have provided insight into how these systems are involved in sleep and its underlying circuitry. For instance, GABA is a major sleep-promoting signal in flies. Recent work shows that the wake-promoting large central clock cells, mentioned above, are the primary recipients of the GABA signal relevant for sleep (Agosto et al. 2008; Parisky et al. 2008; Chung et al. 2009). This creates a system similar to that seen in mammals, where the sleeppromoting neurons become active and shut down the wake-promoting centers of the brain.

\section{Somnogens}

Very early in sleep research, researchers showed that cerebral spinal fluid from a sleep-deprived animal could induce sleep in a rested animal (Legendre and Peiron 1913). Since those early experiments, the hunt has been on for a specific circulating somnogen that tells your body to go to sleep. Many found the idea that it could be adenosine very intriguing. The thinking goes that, as one uses more energy during the day, more and more of the body's ATP is converted to adenosine, signaling a need for sleep, which then restores energy levels (Benington and Heller 1995). 
The data on the role of adenosine are complicated. Mice that carry mutations in either the A2A or A1 adenosine receptor do not show profound changes in sleep (Stenberg et al. 2003; Urade et al. 2003; Huang et al. 2005; Bjorness et al. 2009). This has been problematic for the field, since caffeine is thought to promote arousal by blocking the A2A receptor (Huang et al. 2005). To date, the best evidence for a sleep-promoting effect of adenosine comes from pharmacological studies. However, recently, mice expressing a dominant-negative SNARE protein (this blocks the release of neuroactive molecules) in astrocytes were found to have reduced cortical slow wave oscillations, characteristic of NREM, and also decreased sleep pressure following periods of deprivation (Fellin et al. 2009; Halassa et al. 2009). The reduction in sleep was thought to be due to decreased ATP release from astrocytes, and thereby attenuated buildup of extracellular adenosine. The idea is that, typically, adenosine would act through the Al receptor to suppress synaptic transmission and promote slow wave activity (Fellin et al. 2009). These studies did not map the site of adenosine action, but they provide a basis for further investigation of a function for adenosine in sleep.

Caffeine action has also been studied in the fruit fly, where it acts through the cAMP pathway, rather than the adenosine receptor, to promote wakefulness. In addition, using a cAMP reporter expressed in all neuronal tissue in the fly, Wu et al. (2009) found that the effect of caffeine was quite global and not restricted to a specific region. Thus, while pharmacological treatment of flies with an adenosine agonist was shown to promote sleep (Hendricks et al. 2000), there are as yet no genetic data to support a role of adenosine in fly sleep.

Interestingly, cAMP phosphodiesterase (PDE) is a known target of caffeine, but had been excluded as a possible mechanism to explain the effects of caffeine on sleep in mammals because of the relatively lower affinity of caffeine for PDE. However, in light of a report indicating that the effects of caffeine on immune function in mammals are mediated by PDE inhibition, together with the recent fly data, it is worth re-exploring a role for PDE (Horrigan et al. 2006; Wu et al. 2009). This is particularly important given that the adenosine receptor knockouts have little to no sleep phenotype, and cAMP signaling is clearly involved in mammalian sleep regulation (see below). It should also be noted that the fly experiments involved chronic treatment with caffeine, while the mammalian studies usually deliver it acutely. There may be differences in the mechanisms used under these different conditions.

\section{Identification of genes required for sleep homeostasis}

The big question remains: Why do we sleep? There is now the growing sense that the function of sleep may fall out of its molecular analysis. Since few sleep-regulating molecules are known, studies are under way to identify novel genes required for sleep. These studies include forward genetic screens as well as genetic manipulation of candidate genes, by focusing on changes in sleep amount as a readout of sleep homeostasis. In some cases, the candidate genes are based on hypothesized sleep functions, so as to assess how loss or gain of a specific function affects sleep quantity (see also Table 3).

\section{Genes based on somatic theories of sleep function}

\section{Sleep and the immune response}

Is sleep necessary for normal body functions, such as the immune response and balanced metabolic activity (Van Cauter et al. 1997)? The idea that immune modulators, like cytokines, promote sleep has anecdotal support, since the mounting of an immune response by the body usually results in fatigue and sleepiness. Researchers have focused mainly on two cytokines, interleukin-1B (IL-1B) and tumor necrosis factor- $\alpha$ (TNF- $\alpha$ ) - as sleep-promoting molecules. Mice lacking IL-1B show decreased NREM sleep during their active time, while mice lacking TNF- $\alpha$ show decreased NREM during their sleep time (Fang et al. 1998;

Table 3. Theories for sleep function

\begin{tabular}{|c|c|c|}
\hline Theory & Description & Genetic evidence \\
\hline Somatic function & $\begin{array}{l}\text { Sleep is for the body, such as } \\
\text { for normal immune function } \\
\text { and for normal metabolic activity. }\end{array}$ & $\begin{array}{l}\text { Animals with mutations in the NFK B gene, } \\
\text { TNF- } \alpha \text {, IL-B, ghrelin, and leptin display sleep } \\
\text { phenotypes. Also, immune genes are up-regulated } \\
\text { following periods of wakefulness. }\end{array}$ \\
\hline Cellular metabolic function & $\begin{array}{l}\text { Sleep is for repairing cells; e.g., } \\
\text { removing reactive oxygen species } \\
\text { or replenishing ATP levels. }\end{array}$ & $\begin{array}{l}\text { Oxidative stress pathway genes are up-regulated } \\
\text { following sleep deprivation. }\end{array}$ \\
\hline \multicolumn{3}{|l|}{ Brain functioning } \\
\hline Synaptic downscaling & $\begin{array}{l}\text { Mechanisms that scale down synaptic } \\
\text { strength to maintain relative strength } \\
\text { of different synapses and yet conserve } \\
\text { energy and space in the cell. }\end{array}$ & $\begin{array}{l}\text { Genes involved in synaptic scaling are up-regulated } \\
\text { during sleep. Mutations in cFos and GRIA3 show } \\
\text { alterations in sleep. In QTL analysis for sleep } \\
\text { homeostatic genes, Homerla was found. }\end{array}$ \\
\hline Memory consolidation & $\begin{array}{l}\text { Sleep is important for consolidating } \\
\text { memory in the hippocampus. }\end{array}$ & $\begin{array}{l}\text { Alterations in CREB, PKA, and cAMP signaling alter } \\
\text { sleep, as do alterations in PKG and BDNF. PDE4 is } \\
\text { increased following sleep deprivation, and } \\
\text { pharmacologically blocking this will rescue } \\
\text { deprivation-induced impairments in LTP. }\end{array}$ \\
\hline
\end{tabular}


Krueger et al. 1998). In addition, double knockouts lacking both IL-1B and TNF- $\alpha$ show a greater magnitude of slow wave delta power following sleep deprivation (Baracchi and Opp 2008). From these data, though, one cannot conclude a causal relationship between the immune system and sleep drive. The mutant animals still sleep, and the lowered NREM may just reflect an overlap in immune and sleep circuitry.

Expression profiles undertaken to identify genes whose expression changes with sleep state have also identified genes in the immune response pathway (Cirelli et al. 2005b; Williams et al. 2007). In Drosophila, NFкB (Relish) and other immune response genes have been identified in such screens, and are up-regulated during wakefulness and prolonged wakefulness. In addition, flies with decreased levels of Relish have reduced nighttime sleep (Williams et al. 2007). In the rat cortex also, expression of genes in the immune response pathway is up-regulated during wakefulness, as indicated by microarray studies. These include lysozyme, COX-2, and I-кB $\alpha$ (Cirelli et al. 2005b). However, while the microarray studies support the genetic mutant data, they also do little to address causality. They are nevertheless useful for identifying associations between gene expression profiles and behavioral states.

\section{Sleep and metabolism}

There have long been theories that sleep is important for metabolism (Benington and Heller 1995). This is supported by the potential role for adenosine, and by reports showing associations between glycogen levels and sleep. In addition, there appears to be anatomic overlap in the regulation of sleep and metabolism. For instance, the mammalian hypothalamus is an important control structure for both processes. Recent work in the fly also implicates its major hormonal and metabolic center as an important place for the regulation of sleep (Fig. 1; Foltenyi et al. 2007; Crocker et al. 2010).

Epidermal growth factor receptor (EGFR), a receptor important for cell proliferation and growth through different signaling pathways, is implicated in sleep regulation in Drosophila and C. elegans (Foltenyi et al. 2007; Van Buskirk and Sternberg 2007). Foltenyi et al. (2007) found that increased signaling of the EGFR pathway results in increased sleep. Signaling was increased through gain-offunction mutations of the EGFR ligands in an area of the fly brain homologous to the hypothalamus, known as the pars intercerbralis (PI) (Fig. 1), and was correlated with changes in downstream ERK signaling. Our own recent work showed that wake-promoting effects of octopamine are mediated by insulin-producing cells in the fly brain that are also located in the PI (Crocker et al. 2010).

The EGFR pathway is also implicated in C. elegans sleep. The $C$. elegans model for sleep focuses on a developmentally regulated state of quiescence, called lethargus, that occurs in conjunction with larval moults. Interestingly, lethargus is regulated by the worm homolog of the circadian gene per, and is associated with synaptogenesis (a hypothesized function of sleep), suggesting that it represents a primordial sleep-like state (Van Buskirk and
Sternberg 2007; Raizen et al. 2008). Overexpression of lin-3 (ligand for EGFR) induces lethargus-like behaviors in worms (Van Buskirk and Sternberg 2007). The receptor Let-23 (EGFR) is found in only a handful of neurons, of which the ALA neurons are responsible for the effect of lin-3 on lethargus (Van Buskirk and Sternberg 2007). These neurons are neuroendocrine in nature, similar to the neurons through which EGF affects sleep in flies. Thus, in the mouse, the fly, and the worm, metabolic and endocrine functions appear to be tied to sleep. Whether it is just an anatomical overlap or a functional overlap still needs to be addressed.

Many mouse mutants with altered metabolic function also show changes in sleep. For instance, mouse knockouts of the ghrelin gene show a slight increase in sleep (Laposky et al. 2008). Correspondingly, leptin-deficient mice have a decrease in NREM sleep and increased fragmentation of sleep (Szentirmai et al. 2007). Mice that do not make growth hormone-releasing hormone (GHRH) and its receptor show significantly less NREM sleep, whereas mice overexpressing growth hormone sleep more (Obal et al. 2001, 2003). Unfortunately, these studies do not address the fundamental question of whether increased hunger in these animals overrides the sleep signal.

More recently, genes important for dealing with cellular stress have been implicated in sleep regulation. Through both differential expression profiles and targeted gene approaches, the gene Bip is implicated as a sleeppromoting factor. Bip is important for the unfolded protein response in the endoplasmic reticulum (ER), and is up-regulated following periods of sleep deprivation in mice (Cirelli et al. 2005b). In addition, flies with altered Bip levels show changes in their homeostatic response to sleep deprivation (Naidoo et al. 2007).

\section{Genes important for synaptic modulation}

One of the current hypotheses for why we sleep is that it allows for, or even promotes, synaptic downscaling (Tononi and Cirelli 2006). This hypothesis is based on the presumption that, during wakefulness, the interaction of animals with their environment leads to the strengthening of some synapses, while others remain the same. It postulates that synaptic downscaling during sleep promotes efficiency in terms of energy and space, while maintaining the relative ratios of the strength of synapses. This hypothesis has been supported in recent years by differential expression studies of genes whose expression changes with sleep/wake state. Many immediate early genes and genes that regulate synaptic strength were identified in these studies. These include NARP and Homerla in the awake rat cortex (Cirelli et al. 2005b). In addition, knockouts of c-Fos (another immediate early gene marking neuronal activity) and Gria3 (AMPA receptor GluR3 subunit) in mice show alterations in their sleep (Shiromani et al. 2000; Steenland et al. 2008). The c-Fos-null animals have more wakefulness and reduced slow wave sleep, and the Gria3 animals show dampened EEG powers across waking and NREM sleep but no changes in total sleep amount (Shiromani et al. 2000; Steenland et al. 2008). The Homer1a gene was also identified in QTL analysis as a strong candidate for a gene underlying sleep 
homeostasis and magnitude of delta power (Maret et al. 2007; Mackiewicz et al. 2008). More recent work by Gilestro et al. (2009) monitored the expression of synaptic genes over the course of the normal sleep:wake cycle, as well as following periods of sleep deprivation in Drosophila. They discovered that expression of synaptic proteins decreases in a sleep-dependent manner (Gilestro et al. 2009).

While these results are tantalizing, it may be premature to conclude that synaptic downscaling is a function of sleep. In order to definitively address this question, genetic tools that allow one to better visualize circuitry and synapses need to be employed. Zebrafish provide an ideal model organism for such approaches, since they are translucent and thus allow one to visualize changes in synapses.

\section{Ion channels and channel-regulating molecules}

Forward genetic screens in the fruit fly have identified sleep-regulating genes that are important for $\mathrm{K}^{+}$channel activity. The minisleep ( $\mathrm{mns}$ ) fly line, isolated in a genetic screen, carries a mutation in the Shaker $\mathrm{K}^{+}$channel (Cirelli et al. 2005a). Based on the mns phenotype, a mutation in the $\beta$ subunit of Shaker, hyperkinetic, was tested, and was also found to reduce sleep (Bushey et al. 2007). An independent genetic screen isolated a short sleeping mutant known as sleepless that also affects activity of the Shaker $\mathrm{K}^{+}$channel (Wu et al. 2010; Koh et al. 2008). Both the sleepless and the Shaker mutants sleep very little at night. Interestingly, neither of these mutations has been rescued in a specific area of the fly brain, suggesting that a global change in synaptic properties underlies sleep.

These mutants have other phenotypes as well, such as shorter life span, ether sensitivity, and, in the case of Shaker, a learning and memory deficit (Bushey et al. 2007; Koh et al. 2008). In the case of sleepless, it was found that the ether sensitivity could be rescued independently of the sleep phenotype (Koh et al. 2008). It would be interesting to know whether life span can also be rescued independently.

In mice, the large number of ion channels, subunits, and distribution has made it difficult to identify the role these play in sleep. Indeed, based on the redundancy of $\mathrm{K}^{+}$channels in mammals, it is unlikely that mutations in these would have been found through forward genetic screens, since such screens typically require strong phenotypes. However, reverse genetic approaches have allowed the detection of subtle sleep phenotypes in mice mutant for Shaker-like channels (Vyazovskiy et al. 2002; Espinosa et al. 2004, 2008; Douglas et al. 2007). In addition, mice lacking an $\mathrm{N}$-type calcium channel $\alpha 1 \mathrm{~b}$ subunit have a sleep phenotype. This subunit is important in many of the major anatomical regions important for arousal, including the locus coeruleus and the dorsal raphe (Beuckmann et al. 2003). Accordingly, mice lacking this subunit show hyperactivity (increased consolidation of REM and increased NREM-to-wake transitions). These mice also show decreased power during NREM sleep, implying decreased sleep drive. When the $\alpha 1 \mathrm{G}$ subunit of the T-type $\mathrm{Ca}^{++}$ channel is knocked out globally in mice, they display decreased NREM cortical EEG oscillations, due to the inability of thalamic relay neurons to go into a bursting mode, and increased fragmentation of sleep (Lee et al. 2004; Anderson et al. 2005). The same phenotype is observed when this subunit is knocked out specifically in the thalamus, thereby verifying lesion studies that implicate the thalamus in arousal and in the generation of the sleep EEG (Anderson et al. 2005). Along the same lines, mice lacking the SK2 channel $\left(\mathrm{a} \mathrm{K} \mathrm{K}^{+}\right.$channel specific to the dendrites of the nucleus reticularis of the thalamus) show weakened delta waves and spindles in the EEG, which results in very fragmented sleep (Cueni et al. 2008). This $\mathrm{K}^{+}$channel couples with the T-type $\mathrm{Ca}^{+}$channels described above. These animals provide an ideal model to determine how specific electrical attributes of cortical neurons correlate with sleep EEGs.

\section{Genes involved in learning and memory}

In both mice and flies, many genes important for learning and memory have been targeted for sleep analysis. These include, but are not limited to, CREB, protein kinase A (PKA), cAMP, ERK, cGMP, and some of the ion channels listed above.

Manipulations of CREB, a transcription regulator, influence total sleep and NREM in mice (Graves et al. 2003b). Thus, mice lacking either one of two CREB isoforms in the entire brain show altered sleep. These animals spend less time awake and have longer bouts of NREM sleep. They also have altered memory formation and reduced longterm potentiation (LTP) (Graves et al. 2002). The effect on LTP and hippocampal-dependent memory formation is similar to what is seen following a period of sleep deprivation (Graves et al. 2003a). More recently, effects of sleep deprivation on LTP were rescued by an inhibitor of a specific PDE, supporting the idea that the effects of sleep on hippocampal plasticity are mediated by cAMP signaling (Vecsey et al. 2009). Another molecule implicated in learning and memory and sleep is brain-derived neurotrophic factor (BDNF) (Monteggia et al. 2004). Levels of BDNF increase with increased exploratory behavior, which also increases the depth of delta power during sleep (Huber et al. 2007). The role of BDNF may not be independent of CREB, since BDNF is a major target of CREB.

The mammalian work linking sleep with learning and memory genes has been largely limited to analysis of BDNF and CREB. In the fly, this is not the case. There are many tools available to fly researchers that allow one to probe very specific parts of these pathways. Two important intracellular pathways implicated in sleep are the cAMPPKA pathway and the ERK pathway (Hendricks et al. 2001; Joiner et al. 2006; Foltenyi et al. 2007). It is thought that the cAMP pathway provides a wake-promoting signaling pathway, whereas the ERK pathway, at least within a subset of neurons, is sleep-promoting. Mutants and transgenic flies carrying manipulations of these different signaling pathways have also helped to locate anatomical regions important for sleep regulation. In the case of cAMP and PKA, an area known as the mushroom body is important (Fig. 1; Joiner et al. 2006; Pitman et al. 2006). The mushroom body is similar to the hippocampus in mammals, in that it is involved in memory formation (Heisenberg 2003). 
Bushey et al. (2007) correlated short sleep with shortterm memory deficits in flies. They specifically looked at hyperkinetic flies and variations of Shaker mutants and found that, regardless of other behaviors, the sleep phenotype (short sleep) and decreased memory are associated. It is currently unknown whether short sleep causes a memory deficit or vice versa. Following a period of sleep deprivation, learning is impaired, but the converse has also been argued (Cirelli 2009). Genetically manipulating the mushroom body in the fly, as described above, can produce either short or long sleepers, depending on the region targeted. In addition, flies exposed to an enriched environment appear to sleep more (Ganguly-Fitzgerald et al. 2006; Donlea et al. 2009). This increase in sleep is dependent on cAMP, presumably because it involves memory consolidation, and can be rescued within the central clock cells in the fly (Fig. 1; Donlea et al. 2009).

As in flies and mammals, cyclic nucleotide pathways affect lethargus in worms. Worms deficient in egl-4 (cGMPdependent kinase) have reduced periods of quiescence, whereas gain-of-function mutants of egl-4 show enhanced quiescence (Raizen et al. 2008). Similar sleep phenotypes are observed in flies that have alterations in cGMPdependent kinase (Raizen et al. 2008). Also, a mouse conditional brain knockout of cGMP-dependent protein kinase type 1 causes increased sleep fragmentation, exaggerated delta rebound following deprivation, and reduced REM sleep (Langmesser et al. 2009). Thus, a role for cGMP in sleep is conserved across evolution. cGMP protein kinase mutants also have defects in learning and memory, in both mice and flies (Feil et al. 2009).

While the analysis of genetic mutants may not have provided major breakthroughs in our knowledge of sleep up to this point, it has been critical in many respects. First, even where the studies have been purely confirmatory, they have served to unequivocally establish a particular mechanism or a role for a specific molecule in sleep. This extends also to genes underlying diseases associated with sleep problems: Sleep disturbances have been reported in people with Angelman syndrome and Fragile X syndrome, and, in both cases, knockout of the relevant gene in mice and/or flies has produced a circadian/sleep phenotype (Dockendorff et al. 2002; Y Wu et al. 2008; Zhang et al. 2008). In many cases, genetic mutants have helped to resolve discrepancies. Moreover, forward genetic screens in model organisms are already identifying new molecules, and will likely also lead to paradigmshifting findings. Such screens immediately associate gene with function and, importantly, they are done in a completely unbiased fashion, which arguably is the best approach toward a process about which little is known. Finally, the anatomic studies conducted in invertebrates already indicate an overlap between sleep and other aspects of physiology; e.g., metabolism. These findings could be invaluable for what they suggest about sleep function. Importantly, they can be followed up easily with experiments designed to address specific hypotheses.

The future potential of genetic approaches is also tremendous, given the rapid development of novel genetic tools and technology. For example, the use of optogenetic tools has already provided insight into the orexin pathway (Adamantidis et al. 2007; Zhang et al. 2007). In addition, inducible and tissue-specific gene expression, which will allow precise targeting of genetic manipulations, will undoubtedly clarify the sleep function of genes whose role is currently controversial. In an interesting merge of pharmacological methods and genetic tools, viruses have been developed that can be introduced into specific anatomic areas (Adachi et al. 2008; Fuller et al. 2008). The fly provides many unique genetic techniques, some of which have been discussed in the course of this review. Recently there has been an explosion of tools that allow scientists to alter activity/signaling within a subset of neurons; these include, but are not limited to, expression of $\mathrm{Na}^{+}$channels, $\mathrm{K}^{+}$channels, $\mathrm{Ca}^{++}$channels, and vesicular release blockers (for review, see Hodge 2009). This is a huge advance for behavioral studies, because electrophysiological stimulation of neurons to alter behavior has to be done in a very artificial, controlled environment in mammals, but in flies, since this is done genetically, they are able to behave normally in an unrestricted environment. cAMP monitors have also been developed that can be specifically expressed in certain cells and do not rely on bath application or injection (Shafer et al. 2008). Finally, in flies and mammals, techniques have been developed to specifically tag a subset of neurons in the brains and determine their expression profile (Zong et al. 2005; Miller et al. 2009).

\section{Conclusion}

Genetics can tell us a lot about what sleep does for organisms, but the potential of this approach has only just started to be recognized in the sleep field. With the generation of conditional and anatomically restricted knockouts (or knock-ins) in mice, we are on the verge of answering many questions. These include determining the roles of adenosine and BDNF in sleep and memory. In flies, anatomically and/or temporally restricted expression of sleep-regulating transgenes has already been performed. These approaches have provided great insight into the role of specific signaling pathways in sleep. In the future, this technology will be used to rescue sleep mutants in a region-specific manner, although some of these mutations, such as in ion channels, may turn out to have global effects that cannot be rescued in specific areas. However, the real power of the fly, worm, and fish models lies in their amenability to unbiased genetic screens. With a process like sleep, about which little is known, we suggest that the best approach is one that is not associated with any preconceived assumptions, since it allows the identification of completely novel mechanisms and pathways. Thus far, it appears that redundancy and/or compensation in mammals will make it difficult to detect strong phenotypes through genetic screens. The fly work, on the other hand, has already demonstrated that mutants with strong phenotypes can be identified.

While forward genetic screens in mice may not be realistic (or cost-effective), QTL analysis and microarray approaches are yielding potential sleep-regulating genes. The use of the new genetic tools described above will 
allow researchers to investigate whether or not these genes specifically affect sleep. An example of this is provided by the Rarb story, where the gene was identified through QTL mapping, and then specific targeted disruptions of this gene were undertaken.

At this point, there is no evidence that a single gene, or subset of genes, acting in a specific subset of neurons is responsible for sleep. It is more likely that sleep is a network phenomenon. It is also likely that there will be many hypotheses for why we sleep and strong evidence for each, since many of the neurotransmitters and signaling pathways that keep us awake serve other functions. For instance, orexin is apparently involved in both feeding behavior and maintaining wakefulness. Sleep deprivation results in several impaired processes, some of which may turn out to reflect consequences of increased wakefulness rather than indicating an actual function of sleep. With the advancement of new genetic tools, it is likely that we will soon see experiments directly testing some of these hypotheses, such as cellular metabolic function and synaptic scaling. From the data discussed in this review, it is likely that sleep is important for overall homeostatic regulation of the entire organism, possibly down to within-the-cell homeostasis. It is clear that sleep is a very basic process, and that studying it in model organisms will provide significant insight into why we sleep. In general, advances in genetics in all model organisms will provide a wealth of knowledge for the sleep field in the coming years.

\section{Acknowledgments}

We thank Xiangzhong Zheng for comments on the manuscript. Work discussed here was supported by grants from the NINDS and NIA to A.S., and by a National Research Service Award to A.C.. A.S. is an Investigator of the HHMI.

\section{References}

Adachi M, Barrot M, Autry AE, Theobald D, Monteggia LM. 2008. Selective loss of brain-derived neurotrophic factor in the dentate gyrus attenuates antidepressant efficacy. Biol Psychiatry 63: 642-649.

Adamantidis AR, Zhang F, Aravanis AM, Deisseroth K, de Lecea L. 2007. Neural substrates of awakening probed with optogenetic control of hypocretin neurons. Nature 450: 420-424.

Aeschbach D, Borbely AA. 1993. All-night dynamics of the human sleep EEG. J Sleep Res 2: 70-81.

Agosto J, Choi JC, Parisky KM, Stilwell G, Rosbash M, Griffith LC. 2008. Modulation of GABAA receptor desensitization uncouples sleep onset and maintenance in Drosophila. Nat Neurosci 11: 354-359.

Alexandre C, Popa D, Fabre V, Bouali S, Venault P, Lesch KP, Hamon M, Adrien J. 2006. Early life blockade of 5-hydroxytryptamine 1A receptors normalizes sleep and depressionlike behavior in adult knock-out mice lacking the serotonin transporter. I Neurosci 26: 5554-5564.

Allada R, Siegel JM. 2008. Unearthing the phylogenetic roots of sleep. Curr Biol 18: R670-R679. doi: 10.1016/j.cub.2008.06.033.

Ambrosius U, Lietzenmaier S, Wehrle R, Wichniak A, Kalus S, Winkelmann J, Bettecken T, Holsboer F, Yassouridis A, Friess E. 2008. Heritability of sleep electroencephalogram. Biol Psychiatry 64: 344-348.

Anaclet C, Parmentier R, Ouk K, Guidon G, Buda C, Sastre JP, Akaoka H, Sergeeva OA, Yanagisawa M, Ohtsu H, et al.
2009. Orexin/hypocretin and histamine: Distinct roles in the control of wakefulness demonstrated using knock-out mouse models. I Neurosci 29: 14423-14438.

Anderson MP, Mochizuki T, Xie J, Fischler W, Manger JP, Talley EM, Scammell TE, Tonegawa S. 2005. Thalamic Cav3.1 T-type $\mathrm{Ca}^{2+}$ channel plays a crucial role in stabilizing sleep. Proc Natl Acad Sci 102: 1743-1748.

Andretic R, Franken P, Tafti M. 2008a. Genetics of sleep. Annu Rev Genet 42: 361-388.

Andretic R, Kim YC, Jones FS, Han KA, Greenspan RJ. 2008b. Drosophila D1 dopamine receptor mediates caffeine-induced arousal. Proc Natl Acad Sci 105: 20392-20397.

Anokhin A, Steinlein O, Fischer C, Mao Y, Vogt P, Schalt E, Vogel F. 1992. A genetic study of the human low-voltage electroencephalogram. Hum Genet 90: 99-112.

Archer SN, Robilliard DL, Skene DJ, Smits M, Williams A, Arendt I, von Schantz M. 2003. A length polymorphism in the circadian clock gene Per3 is linked to delayed sleep phase syndrome and extreme diurnal preference. Sleep 26: 413-415.

Baracchi F, Opp MR. 2008. Sleep-wake behavior and responses to sleep deprivation of mice lacking both interleukin- $1 \beta$ receptor 1 and tumor necrosis factor- $\alpha$ receptor 1 . Brain Behav Immun 22: 982-993.

Benington JH, Heller HC. 1995. Restoration of brain energy metabolism as the function of sleep. Prog Neurobiol 45: 347360.

Berridge CW. 2008. Noradrenergic modulation of arousal. Brain Res Rev 58: 1-17.

Beuckmann CT, Sinton CM, Miyamoto N, Ino M, Yanagisawa M. 2003. N-type calcium channel $\alpha 1 B$ subunit (Cav2.2) knock-out mice display hyperactivity and vigilance state differences. J Neurosci 23: 6793-6797.

Bjorness TE, Kelly CL, Gao T, Poffenberger V, Greene RW. 2009. Control and function of the homeostatic sleep response by adenosine A1 receptors. I Neurosci 29: 1267-1276.

Borbely AA. 1982. A two process model of sleep regulation. Hum Neurobiol 1: 195-204.

Boutrel B, Franc B, Hen R, Hamon M, Adrien J. 1999. Key role of 5 -HT1B receptors in the regulation of paradoxical sleep as evidenced in 5-HT1B knock-out mice. I Neurosci 19: 32043212 .

Boutrel B, Monaca C, Hen R, Hamon M, Adrien J. 2002. Involvement of 5-HT1A receptors in homeostatic and stressinduced adaptive regulations of paradoxical sleep: Studies in 5-HT1A knock-out mice. J Neurosci 22: 4686-4692.

Bushey D, Huber R, Tononi G, Cirelli C. 2007. Drosophila Hyperkinetic mutants have reduced sleep and impaired memory. J Neurosci 27: 5384-5393.

Carpen JD, Archer SN, Skene DJ, Smits M, von Schantz M. 2005. A single-nucleotide polymorphism in the $5^{\prime}$-untranslated region of the hPER2 gene is associated with diurnal preference. I Sleep Res 14: 293-297.

Carpen JD, von Schantz M, Smits M, Skene DJ, Archer SN. 2006. A silent polymorphism in the PER1 gene associates with extreme diurnal preference in humans. I Hum Genet 51: $1122-1125$.

Chang HY, Grygoruk A, Brooks ES, Ackerson LC, Maidment NT, Bainton RJ, Krantz DE. 2006. Overexpression of the Drosophila vesicular monoamine transporter increases motor activity and courtship but decreases the behavioral response to cocaine. Mol Psychiatry 11: 99-113.

Chemelli RM, Willie JT, Sinton CM, Elmquist JK, Scammell T, Lee C, Richardson JA, Williams SC, Xiong Y, Kisanuki Y, et al. 1999. Narcolepsy in orexin knockout mice: Molecular genetics of sleep regulation. Cell 98: 437-451. 
Chung BY, Kilman VL, Keath JR, Pitman JL, Allada R. 2009. The GABA(A) receptor RDL acts in peptidergic PDF neurons to promote sleep in Drosophila. Curr Biol 19: 386-390.

Church DM, Goodstadt L, Hillier LW, Zody MC, Goldstein S, She X, Bult CJ, Agarwala R, Cherry JL, DiCuccio M, et al. 2009. Lineage-specific biology revealed by a finished genome assembly of the mouse. PLoS Biol 7: e1000112. doi: 10.1371/ journal/bio. 100042 .

Cirelli C. 2009. The genetic and molecular regulation of sleep: From fruit flies to humans. Nat Rev Neurosci 10: 549-560.

Cirelli C, Bushey D, Hill S, Huber R, Kreber R, Ganetzky B, Tononi G. 2005a. Reduced sleep in Drosophila Shaker mutants. Nature 434: 1087-1092.

Cirelli C, LaVaute TM, Tononi G. 2005b. Sleep and wakefulness modulate gene expression in Drosophila. I Neurochem 94: 1411-1419.

Cope DW, Hughes SW, Crunelli V. 2005. GABAa receptor mediated tonic inhibition in thalamic neurons. I Neurosci. 25: 11553-11563.

Crocker A, Sehgal A. 2008. Octopamine regulates sleep in Drosophila through protein kinase A-dependent mechanisms. J Neurosci 28: 9377-9385.

Crocker A, Shahidullah M, Levitan IB, Sehgal A. 2010. Identification of a neural circuit that underlies the effects of octopamine on sleep:wake behavior. Neuron 65: 670-681.

Cueni L, Canepari M, Lujan R, Emmenegger Y, Watanabe M, Bond CT, Franken P, Adelman JP, Luthi A. 2008. T-type $\mathrm{Ca}^{2+}$ channels, SK2 channels and SERCAs gate sleep-related oscillations in thalamic dendrites. Nat Neurosci 11: 683-692.

Dauvilliers Y, Maret S, Tafti M. 2005. Genetics of normal and pathological sleep in humans. Sleep Med Rev 9: 91-100.

De Gennaro L, Marzano C, Fratello F, Moroni F, Pellicciari MC, Ferlazzo F, Costa S, Couyoumdiian A, Curcio G, Sforza E, et al. 2008. The electroencephalographic fingerprint of sleep is genetically determined: A twin study. Ann Neurol 64: $455-460$.

Dockendorff TC, Su HS, McBride SM, Yang Z, Choi CH, Siwicki KK, Sehgal A, Jongens TA. 2002. Drosophila lacking dfmr1 activity show defects in circadian output and fail to maintain courtship interest. Neuron 34: 973-984.

Donlea JM, Ramanan N, Shaw PJ. 2009. Use-dependent plasticity in clock neurons regulates sleep need in Drosophila. Science 324: 105-108.

Douglas CL, Vyazovskiy V, Southard T, Chiu SY, Messing A, Tononi G, Cirelli C. 2007. Sleep in Kcna2 knockout mice. BMC Biol 5: 42. doi: 10.1186/1741-7007-5-42.

Dumermuth G, Lange B, Lehmann D, Meier CA, Dinkelmann R, Molinari L. 1983. Spectral analysis of all-night sleep EEG in healthy adults. Eur Neurol 22: 322-339.

Dzirasa K, Ribeiro S, Costa R, Santos LM, Lin SC, Grosmark A, Sotnikova TD, Gainetdinov RR, Caron MG, Nicolelis MA. 2006. Dopaminergic control of sleep-wake states. J Neurosci 26: 10577-10589.

Edelson E. 1992. Sleep . Chelsea House, New York.

Espinosa F, Marks G, Heintz N, Joho RH. 2004. Increased motor drive and sleep loss in mice lacking Kv3-type potassium channels. Genes Brain Behav 3: 90-100.

Espinosa F, Torres-Vega MA, Marks GA, Joho RH. 2008. Ablation of Kv3.1 and Kv3.3 potassium channels disrupts thalamocortical oscillations in vitro and in vivo. $J$ Neurosci 28: 5570-5581.

Fang J, Wang Y, Krueger JM. 1998. Effects of interleukin-1 $\beta$ on sleep are mediated by the type I receptor. Am I Physiol 274: R655-R660.

Feil R, Holter SM, Weindl K, Wurst W, Langmesser S, Gerling A, Feil S, Albrecht U. 2009. cGMP-dependent protein kinase I, the circadian clock, sleep and learning. Commun Integr Biol 2: 298-301.

Fellin T, Halassa MM, Terunuma M, Succol F, Takano H, Frank M, Moss SJ, Haydon PG. 2009. Endogenous nonneuronal modulators of synaptic transmission control cortical slow oscillations in vivo. Proc Natl Acad Sci 106: 15037-15042.

Foltenyi K, Greenspan RJ, Newport JW. 2007. Activation of EGFR and ERK by rhomboid signaling regulates the consolidation and maintenance of sleep in Drosophila. Nat Neurosci 10: 1160-1167.

Fonck C, Cohen BN, Nashmi R, Whiteaker P, Wagenaar DA, Rodrigues-Pinguet N, Deshpande P, McKinney S, Kwoh S, Munoz J, et al. 2005. Novel seizure phenotype and sleep disruptions in knock-in mice with hypersensitive $\alpha 4^{\star}$ nicotinic receptors. J Neurosci 25: 11396-11411.

Frank MG, Stryker MP, Tecott LH. 2002. Sleep and sleep homeostasis in mice lacking the 5-HT2c receptor. Neuropsychopharmacology 27: 869-873.

Fuller PM, Lu J, Saper CB. 2008. Differential rescue of light- and food-entrainable circadian rhythms. Science 320: 1074-1077.

Gais S, Born J. 2004. Low acetylcholine during slow-wave sleep is critical for declarative memory consolidation. Proc. Natl. Acad. Sci. 101: 2140-2144.

Ganguly-Fitzgerald I, Donlea J, Shaw PJ. 2006. Waking experience affects sleep need in Drosophila. Science 313: 17751781.

Gilestro GF, Tononi G, Cirelli C. 2009. Widespread changes in synaptic markers as a function of sleep and wakefulness in Drosophila. Science 324: 109-112.

Gong H, McGinty D, Guzman-Marin R, Chew KT, Stewart D, Szymusiak R. 2004. Activation of c-fos in GABAergic neurones in the preoptic area during sleep and in response to sleep deprivation. J Physiol 556: 935-946.

Goutagny R, Comte JC, Salvert D, Gomeza J, Yamada M, Wess J, Luppi PH, Fort P. 2005. Paradoxical sleep in mice lacking M3 and M2/M4 muscarinic receptors. Neuropsychobiology 52: $140-146$

Graves L, Dalvi A, Lucki I, Blendy JA, Abel T. 2002. Behavioral analysis of CREB $\alpha \delta$ mutation on a B6/129 F1 hybrid background. Hippocampus 12: 18-26.

Graves LA, Heller EA, Pack AI, Abel T. 2003a. Sleep deprivation selectively impairs memory consolidation for contextual fear conditioning. Learn Mem 10: 168-176.

Graves LA, Hellman K, Veasey S, Blendy JA, Pack AI, Abel T. 2003b. Genetic evidence for a role of CREB in sustained cortical arousal. J Neurophysiol 90: 1152-1159.

Halassa MM, Florian C, Fellin T, Munoz JR, Lee SY, Abel T, Haydon PG, Frank MG. 2009. Astrocytic modulation of sleep homeostasis and cognitive consequences of sleep loss. Neuron 61: 213-219.

Hallmayer J, Faraco J, Lin L, Hesselson S, Winkelmann J, Kawashima M, Mayer G, Plazzi G, Nevsimalova S, Bourgin $P$, et al. 2009. Narcolepsy is strongly associated with the T-cell receptor $\alpha$ locus. Nat Genet 41: 708-711.

He Y, Jones CR, Fujiki N, Xu Y, Guo B, Holder JL Jr, Rossner MJ, Nishino S, Fu YH. 2009. The transcriptional repressor DEC2 regulates sleep length in mammals. Science 325: 866-870.

Hedlund PB, Huitron-Resendiz S, Henriksen SJ, Sutcliffe JG. 2005. 5-HT7 receptor inhibition and inactivation induce antidepressantlike behavior and sleep pattern. Biol Psychiatry 58: 831-837.

Heisenberg M. 2003. Mushroom body memoir: From maps to models. Nat Rev Neurosci 4: 266-275.

Hendricks JC, Finn SM, Panckeri KA, Chavkin J, Williams JA, Sehgal A, Pack AI. 2000. Rest in Drosophila is a sleep-like state. Neuron 25: 129-138. 
Hendricks JC, Williams JA, Panckeri K, Kirk D, Tello M, Yin JC, Sehgal A. 2001. A non-circadian role for cAMP signaling and CREB activity in Drosophila rest homeostasis. Nat Neurosci 4: $1108-1115$.

Hendricks JC, Lu S, Kume K, Yin JC, Yang Z, Sehgal A. 2003. Gender dimorphism in the role of cycle (BMAL1) in rest, rest regulation, and longevity in Drosophila melanogaster. J Biol Rhythms 18: 12-25.

Hodge JJ. 2009. Ion channels to inactivate neurons in Drosophila. Front Mol Neurosci 2: 13. doi: 10.3389/neuro.02013.2009.

Honma S, Kawamoto T, Takagi Y, Fujimoto K, Sato F, Noshiro M, Kato Y, Honma K. 2002. Dec1 and Dec2 are regulators of the mammalian molecular clock. Nature 419: 841-844.

Horrigan LA, Kelly JP, Connor TJ. 2006. Immunomodulatory effects of caffeine: Friend or foe? Pharmacol Ther 111: 877-892.

Hu WP, Li JD, Zhang C, Boehmer L, Siegel JM, Zhou QY. 2007. Altered circadian and homeostatic sleep regulation in prokineticin 2-deficient mice. Sleep 30: 247-256.

Huang ZL, Qu WM, Eguchi N, Chen JF, Schwarzschild MA, Fredholm BB, Urade Y, Hayaishi O. 2005. Adenosine A2A, but not $\mathrm{A} 1$, receptors mediate the arousal effect of caffeine. Nat Neurosci 8: 858-859.

Huber R, Hill SL, Holladay C, Biesiadecki M, Tononi G, Cirelli C. 2004. Sleep homeostasis in Drosophila melanogaster. Sleep 27: 628-639.

Huber R, Tononi G, Cirelli C. 2007. Exploratory behavior, cortical BDNF expression, and sleep homeostasis. Sleep 30: 129-139.

Hunsley MS, Palmiter RD. 2003. Norepinephrine-deficient mice exhibit normal sleep-wake states but have shorter sleep latency after mild stress and low doses of amphetamine. Sleep 26: 521-526.

Hunsley MS, Curtis WR, Palmiter RD. 2006. Behavioral and sleep/wake characteristics of mice lacking norepinephrine and hypocretin. Genes Brain Behav 5: 451-457.

Joiner WJ, Crocker A, White BH, Sehgal A. 2006. Sleep in Drosophila is regulated by adult mushroom bodies. Nature 441: 757-760.

Jouvet M. 1968. Insomnia and decrease of cerebral 5-hydroxytryptamine after destruction of the raphe system in the cat. Adv Pharmacol 6(Pt B): 265-279.

Kaslin J, Nystedt JM, Ostergard M, Peitsaro N, Panula P. 2004. The orexin/hypocretin system in zebrafish is connected to the aminergic and cholinergic systems. J Neurosci 24: 2678-2689.

Kloss B, Price JL, Saez L, Blau J, Rothenfluh A, Wesley CS, Young MW. 1998. The Drosophila clock gene double-time encodes a protein closely related to human casein kinase Iepsilon. Cell 94: 97-107.

Koh K, Joiner WJ, Wu MN, Yue Z, Smith CJ, Sehgal A. 2008. Identification of SLEEPLESS, a sleep-promoting factor. Science 321: 372-376.

Konopka RJ, Benzer S. 1971. Clock mutants of Drosophila melanogaster. Proc Natl Acad Sci 68: 2112-2116.

Kopp C, Rudolph U, Keist R, Tobler I. 2003. Diazepam-induced changes on sleep and the EEG spectrum in mice: Role of the $\alpha 3$-GABA(A) receptor subtype. Eur J Neurosci 17: 2226-2230.

Kopp C, Rudolph U, Low K, Tobler I. 2004. Modulation of rhythmic brain activity by diazepam: GABA(A) receptor subtype and state specificity. Proc Natl Acad Sci 101: 3674-3679.

Krueger JM, Fang J, Taishi P, Chen Z, Kushikata T, Gardi J. 1998. Sleep. A physiologic role for IL- $1 \beta$ and TNF- $\alpha$. Ann N Y Acad Sci 856: 148-159.

Kume K, Kume S, Park SK, Hirsh J, Jackson FR. 2005. Dopamine is a regulator of arousal in the fruit fly. I Neurosci 25: $7377-$ 7384.
Langmesser S, Franken P, Feil S, Emmenegger Y, Albrecht U, Feil R. 2009. cGMP-dependent protein kinase type I is implicated in the regulation of the timing and quality of sleep and wakefulness. PLoS One 4: e4238. doi: 1371/journal.pone.0004238.

Laposky AD, Homanics GE, Basile A, Mendelson WB. 2001. Deletion of the GABA(A) receptor $\beta 3$ subunit eliminates the hypnotic actions of oleamide in mice. Neuroreport 12: 4143 4147.

Laposky A, Easton A, Dugovic C, Walisser J, Bradfield C, Turek F. 2005. Deletion of the mammalian circadian clock gene BMAL1/Mop3 alters baseline sleep architecture and the response to sleep deprivation. Sleep 28: 395-409.

Laposky AD, Bradley MA, Williams DL, Bass J, Turek FW. 2008. Sleep-wake regulation is altered in leptin-resistant $(\mathrm{db} / \mathrm{db})$ genetically obese and diabetic mice. Am I Physiol Regul Integr Comp Physiol 295: R2059-R2066. doi: 10.1152/ ajpregu.00026.2008.

Lebestky T, Chang JS, Dankert H, Zelnik L, Kim YC, Han KA, Wolf FW, Perona P, Anderson DJ. 2009. Two different forms of arousal in Drosophila are oppositely regulated by the dopamine D1 receptor ortholog DopR via distinct neural circuits. Neuron 64: 522-536.

Lee J, Kim D, Shin HS. 2004. Lack of delta waves and sleep disturbances during non-rapid eye movement sleep in mice lacking $\alpha 1 \mathrm{G}$-subunit of T-type calcium channels. Proc Natl Acad Sci 101: 18195-18199.

Legendre R, Peiron H. 1913. Recherches sur le besoin de sommeil consecutif a une vielle prolongee. $Z$ Allgem Physiol 14: 235-262.

Lena C, Popa D, Grailhe R, Escourrou P, Changeux JP, Adrien J. 2004. $\beta 2$-Containing nicotinic receptors contribute to the organization of sleep and regulate putative micro-arousals in mice. J Neurosci 24: 5711-5718.

Lim C, Chung BY, Pitman JL, McGill JJ, Pradhan S, Lee J, Keegan KP, Choe J, Allada R. 2007. Clockwork orange encodes a transcriptional repressor important for circadian-clock amplitude in Drosophila. Curr Biol 17: 1082-1089.

Lin L, Faraco J, Li R, Kadotani H, Rogers W, Lin X, Qiu X, de Jong PJ, Nishino S, Mignot E. 1999. The sleep disorder canine narcolepsy is caused by a mutation in the hypocretin (orexin) receptor 2 gene. Cell 98: 365-376.

Lowrey PL, Shimomura K, Antoch MP, Yamazaki S, Zemenides PD, Ralph MR, Menaker M, Takahashi JS. 2000. Positional syntenic cloning and functional characterization of the mammalian circadian mutation tau. Science 288: 483-492.

Mackiewicz M, Paigen B, Naidoo N, Pack AI. 2008. Analysis of the QTL for sleep homeostasis in mice: Homerla is a likely candidate. Physiol Genomics 33: 91-99.

Maret S, Franken P, Dauvilliers Y, Ghyselinck NB, Chambon P, Tafti M. 2005. Retinoic acid signaling affects cortical synchrony during sleep. Science 310: 111-113.

Maret S, Dorsaz S, Gurcel L, Pradervand S, Petit B, Pfister C, Hagenbuchle O, O'Hara BF, Franken P, Tafti M. 2007. Homerla is a core brain molecular correlate of sleep loss. Proc Natl Acad Sci 104: 20090-20095.

Miller MR, Robinson KJ, Cleary MD, Doe CQ. 2009. TUtagging: Cell type-specific RNA isolation from intact complex tissues. Nat Methods 6: 439-441.

Mochizuki T, Crocker A, McCormack S, Yanagisawa M, Sakurai T, Scammell TE. 2004. Behavioral state instability in orexin knock-out mice. J Neurosci 24: 6291-6300.

Monteggia LM, Barrot M, Powell CM, Berton O, Galanis V, Gemelli T, Meuth S, Nagy A, Greene RW, Nestler EJ. 2004. Essential role of brain-derived neurotrophic factor in adult hippocampal function. Proc Natl Acad Sci 101: 1082710832 . 
Monti JM, Monti D. 2007. The involvement of dopamine in the modulation of sleep and waking. Sleep Med Rev 11: 113-133.

Monti JM, Pandi-Perumal SR, Jacobs BL, Nutt DJ, ed. 2008 Serotonin and sleep: Molecular, functional and clinical aspects. Birkhauser Verlag AS, Germany.

Naidoo N, Casiano V, Cater J, Zimmerman J, Pack AI. 2007. A role for the molecular chaperone protein BiP/GRP78 in Drosophila sleep homeostasis. Sleep 30: 557-565.

Naylor E, Bergmann BM, Krauski K, Zee PC, Takahashi JS, Vitaterna MH, Turek FW. 2000. The circadian clock mutation alters sleep homeostasis in the mouse. I Neurosci 20: 8138-8143.

Nishino S, Sakurai E, Nevsimalova S, Yoshida Y, Watanabe T, Yanai K, Mignot E. 2009. Decreased CSF histamine in narcolepsy with and without low CSF hypocretin-1 in comparison to healthy controls. Sleep 32: 175-180.

Obal F Jr, Fang J, Taishi P, Kacsoh B, Gardi J, Krueger JM. 2001. Deficiency of growth hormone-releasing hormone signaling is associated with sleep alterations in the dwarf rat. I Neurosci 21: 2912-2918.

Obal F Jr, Alt J, Taishi P, Gardi J, Krueger JM. 2003. Sleep in mice with nonfunctional growth hormone-releasing hormone receptors. Am I Physiol Regul Integr Comp Physiol 284: R131R139. doi: 10.1152/ajpregu.00361.2002.

O'Hara BF, Ding J, Bernat RL, Franken P. 2007. Genomic and proteomic approaches towards an understanding of sleep. CNS Neurol Disord Drug Targets 6: $71-81$.

Ouyang M, Hellman K, Abel T, Thomas SA. 2004. Adrenergic signaling plays a critical role in the maintenance of waking and in the regulation of REM sleep. J Neurophysiol 92: 20712082.

Parisky KM, Agosto J, Pulver SR, Shang Y, Kuklin E, Hodge JJ, Kang K, Liu X, Garrity PA, Rosbash M, et al. 2008. PDF cells are a GABA-responsive wake-promoting component of the Drosophila sleep circuit. Neuron 60: 672-682.

Parmentier R, Ohtsu H, Djebbara-Hannas Z, Valatx JL, Watanabe T, Lin JS. 2002. Anatomical, physiological, and pharmacological characteristics of histidine decarboxylase knock-out mice: Evidence for the role of brain histamine in behavioral and sleep-wake control. J Neurosci 22: 7695-7711.

Pitman JL, McGill JJ, Keegan KP, Allada R. 2006. A dynamic role for the mushroom bodies in promoting sleep in Drosophila. Nature 441: 753-756.

Popa D, Lena C, Fabre V, Prenat C, Gingrich J, Escourrou P, Hamon M, Adrien J. 2005. Contribution of 5-HT2 receptor subtypes to sleep-wakefulness and respiratory control, and functional adaptations in knock-out mice lacking 5-HT2A receptors. J Neurosci 25: 11231-11238.

Prober DA, Rihel J, Onah AA, Sung RJ, Schier AF. 2006. Hypocretin/orexin overexpression induces an insomnia-like phenotype in zebrafish. J Neurosci 26: 13400-13410.

Qu WM, Huang ZL, Xu XH, Matsumoto N, Urade Y. 2008. Dopaminergic D1 and D2 receptors are essential for the arousal effect of modafinil. J Neurosci 28: 8462-8469.

Raizen DM, Zimmerman JE, Maycock MH, Ta UD, You YJ, Sundaram MV, Pack AI. 2008. Lethargus is a Caenorhabditis elegans sleep-like state. Nature 451: 569-572.

Ralph MR, Menaker M. 1988. A mutation of the circadian system in golden hamsters. Science 241: 1225-1227.

Rossant J, McMahon A. 1999. 'Cre'-ating mouse mutants-a meeting review on conditional mouse genetics. Genes Dev 13: $142-145$.

Saper CB, Scammell TE, Lu J. 2005. Hypothalamic regulation of sleep and circadian rhythms. Nature 437: 1257-1263.

Sehgal A. 2004. Molecular biology of circadian rhythms. WileyLiss, Hoboken, N.J.
Shafer OT, Kim DJ, Dunbar-Yaffe R, Nikolaev VO, Lohse MJ, Taghert PH. 2008. Widespread receptivity to neuropeptide PDF throughout the neuronal circadian clock network of Drosophila revealed by real-time cyclic AMP imaging. Neuron 58: 223-237.

Shang Y, Griffith LC, Rosbash M. 2008. Light-arousal and circadian photoreception circuits intersect at the large PDF cells of the Drosophila brain. Proc Natl Acad Sci 105: 1958719594.

Shaw PJ, Tononi G, Greenspan RJ, Robinson DF. 2002. Stress response genes protect against lethal effects of sleep deprivation in Drosophila. Nature 417: 287-291.

Sheeba V, Fogle KJ, Kaneko M, Rashid S, Chou YT, Sharma VK, Holmes TC. 2008a. Large ventral lateral neurons modulate arousal and sleep in Drosophila. Curr Biol 18: 1537-1545.

Sheeba V, Sharma VK, Gu H, Chou YT, O'Dowd DK, Holmes TC. 2008b. Pigment dispersing factor-dependent and -independent circadian locomotor behavioral rhythms. J Neurosci 28: 217227.

Shiromani PJ, Basheer R, Thakkar J, Wagner D, Greco MA, Charness ME. 2000. Sleep and wakefulness in c-fos and fos B gene knockout mice. Brain Res Mol Brain Res 80: 75-87.

Siepka SM, Yoo SH, Park J, Lee C, Takahashi JS. 2007. Genetics and neurobiology of circadian clocks in mammals. Cold Spring Harb Symp Quant Biol 72: 251-259.

Sokolowski MB. 2001. Drosophila: Genetics meets behaviour. Nat Rev Genet 2: 879-890.

Steenland HW, Kim SS, Zhuo M. 2008. GluR3 subunit regulates sleep, breathing and seizure generation. Eur I Neurosci 27: 1166-1173.

Steinlein O, Anokhin A, Yping M, Schalt E, Vogel F. 1992. Localization of a gene for the human low-voltage EEG on 20q and genetic heterogeneity. Genomics 12: 69-73.

Stenberg D, Litonius E, Halldner L, Johansson B, Fredholm BB, Porkka-Heiskanen T. 2003. Sleep and its homeostatic regulation in mice lacking the adenosine A1 receptor. I Sleep Res 12: $283-290$.

Szentirmai E, Kapas L, Sun Y, Smith RG, Krueger JM. 2007. Spontaneous sleep and homeostatic sleep regulation in ghrelin knockout mice. Am I Physiol Regul Integr Comp Physiol 293: R510-R517. doi: 10.1152/ajpregu.00155.2007.

Tafti M, Petit B, Chollet D, Neidhart E, de Bilbao F, Kiss JZ, Wood PA, Franken P. 2003. Deficiency in short-chain fatty acid $\beta$-oxidation affects theta oscillations during sleep. Nat Genet 34: 320-325.

Tobler I. 2005. Phylogeny of sleep regulation. In Principles and practice of sleep medicine (ed. MH Kryger et al.), pp. 77-90. Elsevier/Saunders, Philadelphia, PA.

Tobler I, Borbely AA. 1986. Sleep EEG in the rat as a function of prior waking. Electroencephalogr Clin Neurophysiol 64: 74-76.

Tobler I, Kopp C, Deboer T, Rudolph U. 2001. Diazepaminduced changes in sleep: Role of the $\alpha 1$ GABA(A) receptor subtype. Proc Natl Acad Sci 98: 6464-6469.

Toh KL, Jones CR, He Y, Eide EJ, Hinz WA, Virshup DM, Ptacek LJ, Fu YH. 2001. An hPer2 phosphorylation site mutation in familial advanced sleep phase syndrome. Science 291: 10401043.

Tononi G, Cirelli C. 2006. Sleep function and synaptic homeostasis. Sleep Med Rev 10: 49-62.

Urade Y, Eguchi N, Qu WM, Sakata M, Huang ZL, Chen JF, Schwarzschild MA, Fink JS, Hayaishi O. 2003. Sleep regulation in adenosine A2A receptor deficient mice. Neurology 61: S94-S96.

Vallone D, Pignatelli M, Grammatikopoulos G, Ruocco L, Bozzi Y, Westphal H, Borrelli E, Sadile AG. 2002. Activity, non-selective 
attention and emotionality in dopamine D2/D3 receptor knock-out mice. Behav Brain Res 130: 141-148.

van Beijsterveldt CE, Boomsma DI. 1994. Genetics of the human electroencephalogram (EEG) and event-related brain potentials (ERPs): A review. Hum Genet 94: 319-330.

Van Buskirk C, Sternberg PW. 2007. Epidermal growth factor signaling induces behavioral quiescence in Caenorhabditis elegans. Nat Neurosci 10: 1300-1307.

Van Cauter E, Polonsky KS, Scheen AJ. 1997. Roles of circadian rhythmicity and sleep in human glucose regulation. Endocr Rev 18: 716-738.

Vecsey CG, Baillie GS, Jaganath D, Havekes R, Daniels A, Wimmer M, Huang T, Brown KM, Li XY, Descalzi G, et al. 2009. Sleep deprivation impairs cAMP signalling in the hippocampus. Nature 461: 1122-1125.

Viola AU, Archer SN, James LM, Groeger JA, Lo JC, Skene DI, von Schantz M, Dijk DJ. 2007. PER3 polymorphism predicts sleep structure and waking performance. Curr Biol 17: 613618.

Vyazovskiy VV, Deboer T, Rudy B, Lau D, Borbely AA, Tobler I. 2002. Sleep EEG in mice that are deficient in the potassium channel subunit K.v.3.2. Brain Res 947: 204-211.

Waddington JL, O'Tuathaigh C, O'Sullivan G, Tomiyama K, Koshikawa N, Croke DT. 2005. Phenotypic studies on dopamine receptor subtype and associated signal transduction mutants: Insights and challenges from 10 years at the psychopharmacology-molecular biology interface. Psychopharmacology 181: 611-638.

Webb WB, Agnew HW Jr. 1971. Stage 4 sleep: Influence of time course variables. Science 174: 1354-1356.

Williams JA, Sathyanarayanan S, Hendricks JC, Sehgal A. 2007. Interaction between sleep and the immune response in Drosophila: A role for the NFkB relish. Sleep 30: 389-400.

Winkelmann J, Schormair B, Lichtner P, Ripke S, Xiong L, Jalilzadeh S, Fulda S, Putz B, Eckstein G, Hauk S, et al. 2007. Genome-wide association study of restless legs syndrome identifies common variants in three genomic regions. Nat Genet 39: 1000-1006.

Winsky-Sommerer R, Vyazovskiy VV, Homanics GE, Tobler I. 2007. The EEG effects of THIP (Gaboxadol) on sleep and waking are mediated by the GABA(A) $\delta$-subunit-containing receptors. Eur J Neurosci 25: 1893-1899.

Winsky-Sommerer R, Knapman A, Fedele DE, Schofield CM, Vyazovskiy VV, Rudolph U, Huguenard JR, Fritschy JM, Tobler I. 2008. Normal sleep homeostasis and lack of epilepsy phenotype in GABA A receptor $\alpha 3$ subunit-knockout mice. Neuroscience 154: 595-605.

Wisor JP, Nishino S, Sora I, Uhl GH, Mignot E, Edgar DM. 2001. Dopaminergic role in stimulant-induced wakefulness. J Neurosci 21: 1787-1794.

Wisor JP, DeLorey TM, Homanics GE, Edgar DM. 2002a. Sleep states and sleep electroencephalographic spectral power in mice lacking the $\beta 3$ subunit of the GABA(A) receptor. Brain Res 955: 221-228.

Wisor JP, O’Hara BF, Terao A, Selby CP, Kilduff TS, Sancar A, Edgar DM, Franken P. 2002b. A role for cryptochromes in sleep regulation. BMC Neurosci 3: 20. doi: 10.1186/14712202-3-20.

Wisor JP, Wurts SW, Hall FS, Lesch KP, Murphy DL, Uhl GR, Edgar DM. 2003. Altered rapid eye movement sleep timing in serotonin transporter knockout mice. Neuroreport 14: 233-238.

Wu MN, Koh K, Yue Z, Joiner WJ, Sehgal A. 2008. A genetic screen for sleep and circadian mutants reveals mechanisms underlying regulation of sleep in Drosophila. Sleep 31: 465472.
Wu Y, Bolduc FV, Bell K, Tully T, Fang Y, Sehgal A, Fischer JA. 2008. A Drosophila model for Angelman syndrome. Proc Natl Acad Sci 105: 12399-12404.

Wu MN, Ho K, Crocker A, Yue Z, Koh K, Sehgal A. 2009. The effects of caffeine on sleep in Drosophila require PKA activity, but not the adenosine receptor. I Neurosci 29: 11029-11037.

Wu MN, Joiner WJ, Dean T, Yue Z, Smith CJ, Chen D, Hoshi T, Sehgal A, Koh K. 2010. SLEEPLESS, a Ly-6/neurotoxin family member, regulates the levels, localization and activity of Shaker. Nat Neurosci 13: 69-75.

$\mathrm{Xu}$ Y, Padiath QS, Shapiro RE, Jones CR, Wu SC, Saigoh N, Saigoh K, Ptacek LJ, Fu YH. 2005. Functional consequences of a CKI $\delta$ mutation causing familial advanced sleep phase syndrome. Nature 434: 640-644.

Yokogawa T, Marin W, Faraco J, Pezeron G, Appelbaum L, Zhang J, Rosa F, Mourrain P, Mignot E. 2007. Characterization of sleep in zebrafish and insomnia in hypocretin receptor mutants. PLOS Biol 5: e277. doi: 10.1371/journal.pbio.0050277.

Yuan Q, Joiner WJ, Sehgal A. 2006. A sleep-promoting role for the Drosophila serotonin receptor 1A. Curr Biol 16: 10511062.

Zhang F, Wang LP, Brauner M, Liewald JF, Kay K, Watzke N, Wood PG, Bamberg E, Nagel G, Gottschalk A, et al. 2007. Multimodal fast optical interrogation of neural circuitry. Nature 446: 633-639.

Zhang J, Fang Z, Jud C, Vansteensel MJ, Kaasik K, Lee CC, Albrecht U, Tamanini F, Meijer JH, Oostra BA, et al. 2008. Fragile X-related proteins regulate mammalian circadian behavioral rhythms. Am J Hum Genet 83: 43-52.

Zong H, Espinosa JS, Su HH, Muzumdar MD, Luo L. 2005. Mosaic analysis with double markers in mice. Cell 121: 479492. 


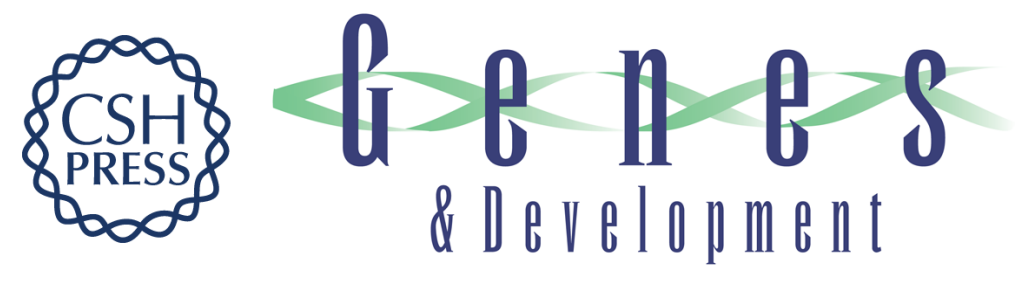

\section{Genetic analysis of sleep}

Amanda Crocker and Amita Sehgal

Genes Dev. 2010, 24:

Access the most recent version at doi:10.1101/gad.1913110

References This article cites 166 articles, 52 of which can be accessed free at: http://genesdev.cshlp.org/content/24/12/1220.full.html\#ref-list-1

License

Email Alerting Receive free email alerts when new articles cite this article - sign up in the box at the top Service right corner of the article or click here.

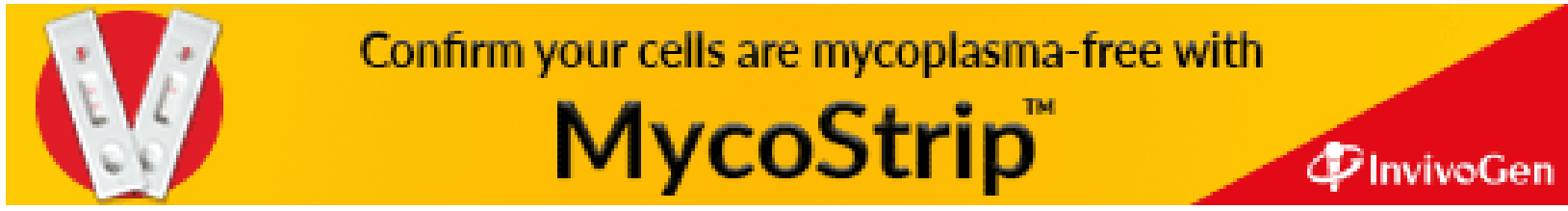

